\title{
A review on the geographical distribution, fruit production and concentration of capsaicinoids in Capsicum annuum var. glabriusculum in the northeastern region of Mexico
}

José Guadalupe Martínez-Ávalos 1, Crystian S. Venegas-Barrera 2, Rodolfo Martínez-Gallegos ${ }^{3}$, Jorge Ariel Torres-Castillo 1, Fabián E. Olazarán Santibáñez ${ }^{1}$, Arturo Mora-Olivo 1, Antonio Guerra Pérez 1, Leonardo U. Arellano-Méndez ${ }^{\text {, }}$ and Fortunato Garza Ocañas 4

1 Instituto de Ecología Aplicada, Universidad Autónoma de Tamaulipas, Calle División del Golfo No 356 Col. Libertad, C.P 87039 Cd. Victoria, Tamaulipas, México; jmartine@uat.edu.mx

2 Tecnológcio Nacional de México / Instituto Tecnológico de Cd. Victoria, Blvd. Emilio Portes Gil N 1301. Cd. Victoria, Tam. C.P. 87010, México; crystian_venegas@itvictoria.edu.mx

${ }^{3}$ Centro de Investigación en Geografía y Geomática “Ing. Jorge L. Tamayo” (CentroGeo), A.C. Contoy 137, Lomas de Padierna, Mex. D.F., CP 14240, México; mgrodlfo@hotmail.com

${ }^{4}$ Facultad de Ciencias Forestales, Universidad Autónoma de Nuevo León: Carretera Linares-Cd. Victoria, km 145. A.P. 41. CP 67700, Linares, Nuevo León, México.

* Correspondence: jmartin@uat.edu.mx; Tel.: +52 (834) 316-2721

\begin{abstract}
Capsicum annuum var. glabriusculum, is a variety of wild chili pepper belonging to the family Solanaceae and is considered as the origin for all cultivated chili species of the world. This species is an important genetic resource for agriculture and food, is widely distributed in northeastern Mexico in altitudes from 0 - 1200 m.a.s.l. This species grows mainly at low altitudes and its upper limit reaches $1000 \mathrm{~m}$., it prefers temperatures above $18.3^{\circ} \mathrm{C}$ and its production and harvest may ocurr at two seasons, one during the beginning of the summer and the main one ocurring in the middle of the autumn in northeast México. It is estimated that the main production occurs in the state of Tamaulipas with 84 tons per year and is harvested from 23 municipalities. Concentration of capseicins and dihydrocapsaicine from wild populations may vary considerably from one location to another in the municipalities, ecotypes and diverse climatic conditions from this wide geographic zone. The high demands of wild chili as well as the variability on concentration of capseicins in fruits are considered as some of the main reasons why intensive cultivation of this species should be carried out in Northeastern Mexico.
\end{abstract}

Key words: distribution, species, wild chilli pepper, Capsicum annuum var. glabriusculum 


\section{Introduction}

The genus Capsicum was originated in Southamerica [1], and it is believed that both Mexico y Central America could also be considered as a diversity spot for the taxa [2,3] and it is classified as an important genetic resource for agriculture and food [4,5]. Capsicum annum L., is one of the cultivated species that has more varieties, it has economical medical and industrial importance in order to obtain food, capsaicinoids, carotenoids and antioxidants [6].

Wild chili pepper populations have a wide geographic distribution in México, Central America and South of the United States of America [7]. Some studies have stated that the wild chili pepper Capsicum annuиm var. glabriusculum (also known as chile piquín, chiltepin or chile del monte) is the progenitor for all cultivated varieties in the world $[1,8,9]$. It is well known that the center of origin for this variety is restricted to two important zones in Mexico. The first one is located at the municipality of Ocampo in the state of Tamaulipas and the second is located Tehuacán, Puebla in the center south zone of Mexico. This since seeds have been found in some caves located in these two sites, and this comes to confirm the beginning of domestication for the species [10,11].

Although there are not official records regarding fruits production under a cultivation system, it is estimated that there are some small cultivation systems for Capsicum annuum var. glabriusculum in the states of Tamaulipas and Sonora [12].

The high demand of fruits of this species has led to carry out studies of its morphology and phytochemistry in order to demonstrate the existence of a great diversity of shapes and colors and concentrations of capsaicine [12,13]. These concentrations are apparently related to precipitation ranges, type of soil, light intensity, temperatures and humidity rates during development of plants and fruit age [14,15].

Some studies states that pungency of red fruits is due to the synthesis and accumulation of capsaicinoids characteristics from the genus Capsicum. These are secondary metabolites originated in the seed testa [16], and capsaicine is the most important element including dihydrocapsaicine, nordihydrocapsaicine, homocapsaicine and homodihydrocapsaicine $[12,13,17]$. It has been confirmed that capsaicin and dihydrocapsaicin build up approximately $90 \%$ of the total content of capsaicinoides in chili $[18,19]$.

According to the genetic studies carried out by $[8,20,21]$, there are high levels of genetic variation in and out of the populations of wild chili peppers in Mexico. Also, there are high differences in the percentage of germination of seeds and a high resistance against the huasteco chili virus (PHV) [22].

This study had as a main aim to make a review on geographic distribution, fruits production and concentrations of capseicins in Capsicum annumm var. glabriusculum in wild populations from Northestern Mexico.

\section{Genus Capsicum}

The genus Capsicum L. (family Solanaceae, subfamily Solanoideae) includes approximately 32 species originated in America $[23,24]$. Five of these varieties have been domesticated as food the next five: C. annuum L., C. frutescens L., C. baccatum L., C. pubescens Ruiz. \& Pav., y C. chinense Jacq. $[25,26]$. However, it is considered that $C$. annuum is the species with higher economic importance and is the only one native from Mexico [27].

C. annuum includes a high variety of shapes, colors and fruits both wild and cultivated [15]. This condition has propitiated a complication on the taxonomy of the species [26]. Studies on these subjects have been carried out throughout the time by different authors [26,28-33].

Although the center of origin of Capsicum is generally recognized from Southamerica [34], studies on isoenzymes indicate that the east of Mexico is the first domestication center of $C$. annuum, including the state of Tamaulipas [27]. In general, most researchers agree that the progenitor for the 
cultivated C. annuum var. annuum, originated from the wild C. annuum var. glabriusculum [35]. Even if the genetic vatriation of wild populations of $C$. annuum has been shown to be high, there is evidence of genetic fluxes occurring between them [36].

Also, the nomenclature used for identifications of wild chillies i.e. C. annuum is variable as e.g. C. annuum var. minus (Fingerh.) Shinners, C. annuum var. minimum (Mill.) Heiser, C. annuum var. aviculare (Dierb.) D'Arcy \& Eshbaugh, y C. annuum var. glabriusculum (Dunal) Heiser \& Pickersgill. C. annum var. glabrisuculum is currently the most commonly accepted variety [37], but recent studies have proposed the use of C. hispidum Dunal var. glabriusculum Dunal [38].

In this study wild chili peppers are recognized as C. annuum var. glabriusculum [39]. They are perennials herbaceous plants, subfrutescents, erected of 0.5 to $2 \mathrm{~m}$ tall; with simple leaves, lanceolate to ovate, of 2-8 cm long; with solitary flowers and a rotated campanulated white corola; the fruit is a berry, ovoid to globose, of 8 to $10 \mathrm{~mm}$ long, green brilliant color changing to orange or red color at maturity; seeds are compressed, pale yellow of $2.5 \mathrm{~mm}$ long [40]. 


\subsection{Traditional uses}

Chili is considered as one the first cultivated plants from Mesoamerica and its continued use is confirmed from 7000 to 5000 years A.C [41,42]. The wild chili pepper also known as chile piquín (Capsicum annuum var. glabriusculum) is very important in the Mexican culture and was used as food since prehispanical times [43]. It is used daily in the Mexican diet, either fresh green or red or dried, in dust, in brine, sauces, salads, moles, stuffed chili, sweet candies and many other presentations [44,45]. Among the main uses of the chili in México are: Ceremonial: Used by curanderos in different ceremonies, such as "cleaning" referring to avoid the bad vibes and is commonly used as cure for evil eye [42]. It is used in ceremonial foods, rituals, and special parties, as for example with the Huicholes [46]. Medicinal: it is known that they were used by prehispanical ethic groups e.g. Aztecs used them to heal tooth ache, ear infections, constipation and labor pains [42], and these types of use was appreciated by the first Spaniards in America [47]. It is used for the digestive system against dyspepsia, is also used for toothache, diarrhea, ear pain, cough and to lower fever, since the capsicine activates blood circulation. There are some medicins that have been obtained from oleoresins from Capsicum spp., they act at the mucosa's alleviating respiratory ailments [42]. May be the most popular remedy using chili in food for hangover [48]. It was also used as punishment by the Aztecs as depicted at the Mendocino Code, they would make bad boys or children to inhale smoke from burning dried chilies. It is still used to stop children from sucking their fingers or to stop them from using the pacifier [25]. Chili is also used mixed up with soap, onions and garlic as repellent against aphids in cultivated plants [42]. Ornamental: Chili is considered as an emblematic plant from the Mexican culture and it is used as ornament in dishes, altars, religious parties and amulets amongst others [42]. Gastronomic: May be this is the most common and important use in Mexico. There are many recipes using wild chili peppers and is considered as an important part of the gastronomy from different regions from Mexico such as the semi-desertic areas and the Sierra Gorda de Querétaro and San Luis Potosí [48-50].

Another very important use of chili is in cosmetics, paints and foods and at the industry it is used to obtain oleorresins, and from them Capsaicina is obtained, and used in human and animal food e.g. birds and even in personal defense $[12,51,52]$.

\subsection{Geographic distribution and ecology}

Capsicum annuum var. glabriusculum is widely distributed in Mexico, south of the United States of America, Central America, Colombia and down up to many regions in Perú [1,7]. In Mexico, this species is registered from all states and is widely found at the coastal zone of the country from Sonora to Chiapas over the Pacific and and from Tamaulipas to Yucatán and Quintana Roo by the Gulf of Mexico [12,53]. At Northeastern Mexico is commonly found from the sea level up to about $1200 \mathrm{~m}$ [12] (Figura 1), is particularly found in disturbed zones in low deciduos forest and thornscrubs [54]. Apparently the main limitant for its growth is altitude and is rarely found at 1000 masl [7], although there are records of some places where it has been found at 1500 masl in the states of Nuevo Leon, Coahuila, Querétaro and Oaxaca $[1,53,54]$. However, a recent study under investigation regarding modelling of potential distribution Martínez-Ávalos and Venegas-Barrera [55], shows that temperature could be one of the main environmental variables controlling its distribution from 18.3 ${ }^{\circ} \mathrm{C}$ on (Figure 2). 
Figure 1. Geographic distribution of Capsicum annuum var. glabriusculim in Mexico.

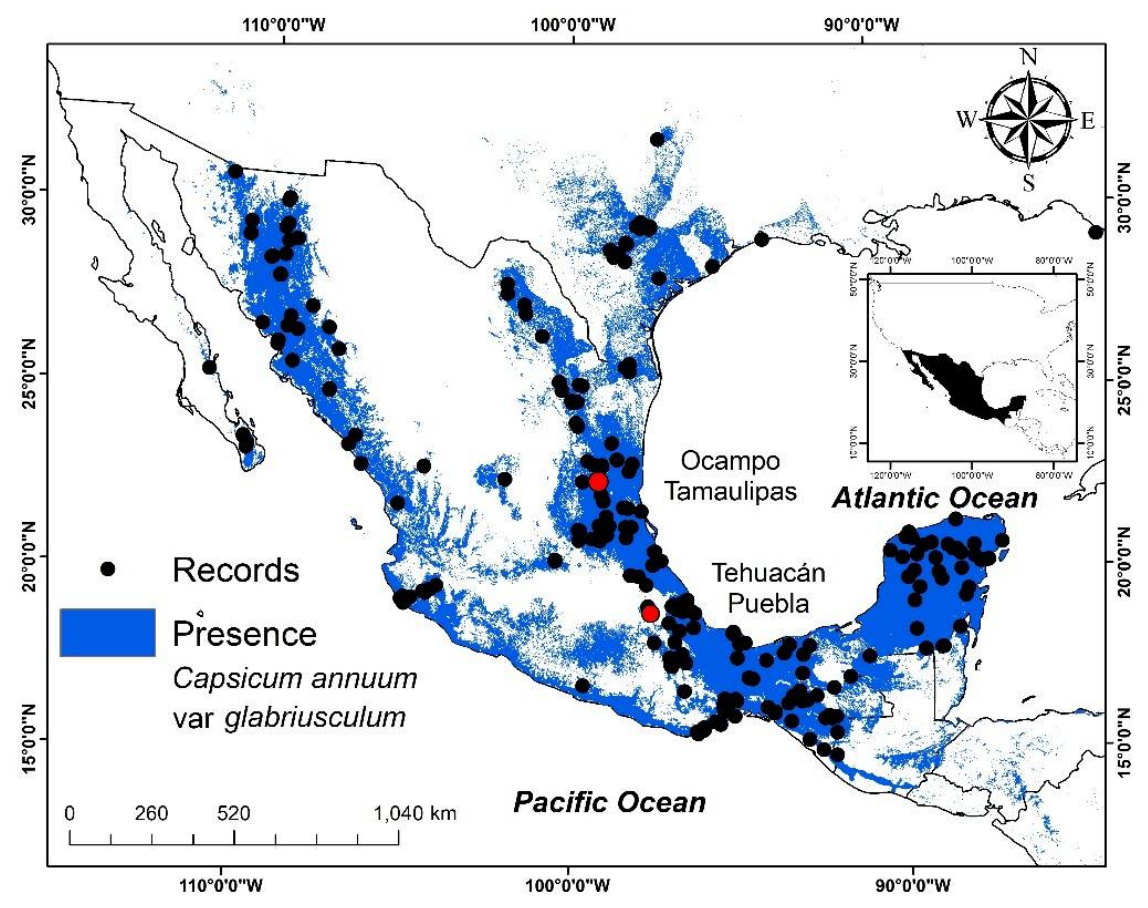

Figure 2. Mean annual temperature contributing to the geographic distribution of Capsicum annuum var. galbriusculum in México [55].

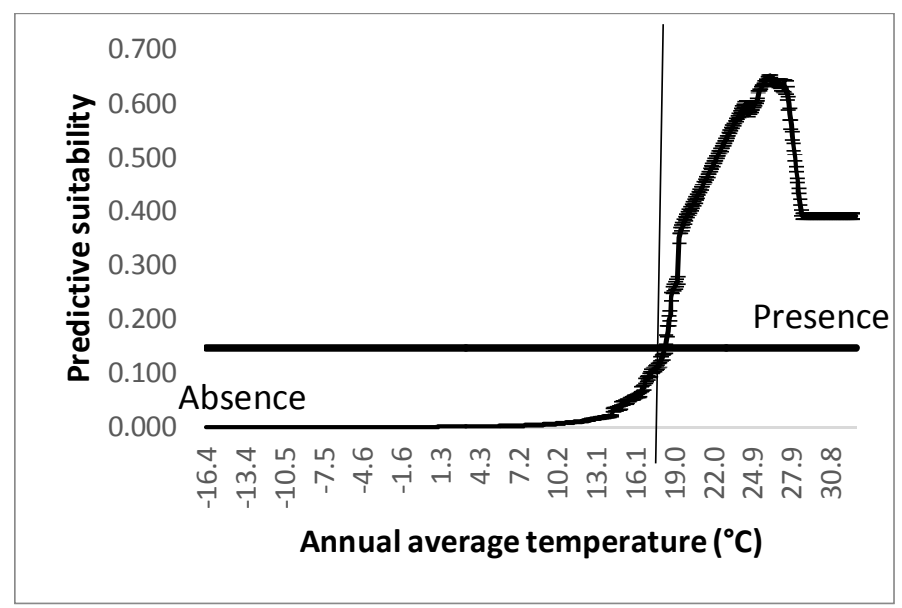




\subsection{Fruits production}

Mexico is one of the main producers of chili fruits in the world with ca. 2.2 million of tons per year [56,57], from a surface planted of $149,000 \mathrm{ha}$. and 12,000 producers participate every year in the process [58]. Considering these data chili has a great economic and social importance as an export product with more than 600,000 tons of green chili a year, and its consumption is increasing every year in the world $[59,60]$.

Consumption of chili Capsicum annuum var. glabriusculum is higher in the north of Mexico and people from nine cities in the states of Coahuila, Nuevo León y Tamaulipas [61] prefer the varieties jalapeño chili (37.3\%), piquín (29.6\%) and serrano (24.0\%), and the cities of Linares and Ciudad Victoria are the main consumers of the variety "piquín". In the last decades the studies on the variety piquín have been increasing due to the attribution of medicinal properties $[62,63]$ and its demand is increasing every year $[64,65]$. Harvest of fruits of wild chili Capsicum annumm var. glabriusculum by people living in rural conditions is an important activity in some Northeatern states (Coahuila, Nuevo León, San Luis Potosí y Tamaulipas) and Northwestern (Baja California Sur, Sonora, Chihuahua and Sinaloa) in Mexico, as the price is always high and they are commercialized both in Mexico and the United States of America [12,20]. In the north of Mexico 65\% of the harvest is used for local consumption and 35\% for commerce [12]. According to Montes Hernández [44], the legal harvest in Mexico may reach a surface of 1,035 ha with an approximate production of 667.40 tons a year with a value of $\$ 1,735.00$ USD. However, it is estimated that illegal harvest might be three times higher than the reported amount by SAGARPA, highlighting the north states: Coahuila, Nuevo León, Baja California Sur, Sonora, Sinaloa y Tamaulipas $[12,61,65,66]$. According to Martínez-Ávalos and Venegas-Barrera [55], show that the production in 23 municipalities in the state of Tamaulipas reached 84 tons a year corresponding to $\$ 641,000$ U.S.D [12] and the main municipalities involved are San Carlos, Villagrán, Soto la Marina, Hidalgo, Abasolo and Victoria (Table 1).

Table 1. Production of Capsicum annuum var. glabriusculum in Tamaulipas, México [55].

\begin{tabular}{r|lcccc}
\multicolumn{1}{c}{ Municipality } & N/Communities & Production/Tons & Costs (M.N) & U.S Dollar \\
\hline $\mathbf{1}$ & San Carlos & 31 & 9.3 & $\$ 1,395,000.00$ & $\$ 71,538.46$ \\
$\mathbf{2}$ & Villagrán & 29 & 8.7 & $\$ 1,305,000.00$ & $\$ 66,923.08$ \\
$\mathbf{3}$ & Soto la Marina & 25 & 7.5 & $\$ 1,125,000.00$ & $\$ 57,692.31$ \\
$\mathbf{4}$ & Hidalgo & 18 & 5.4 & $\$ 810,000.00$ & $\$ 41,538.46$ \\
$\mathbf{5}$ & Abasolo & 15 & 4.5 & $\$ 615,000.00$ & $\$ 31,538.46$ \\
$\mathbf{6}$ & Victoria & 14 & 4.2 & $\$ 630,000.00$ & $\$ 32,307.69$ \\
$\mathbf{7}$ & Méndez & 14 & 4.2 & $\$ 630,000.00$ & 32307.6923 \\
$\mathbf{8}$ & Aldama & 13 & 3.9 & $\$ 585,000.00$ & $\$ 30,000.00$ \\
$\mathbf{9}$ & Guémez & 13 & 3.9 & $\$ 585,000.00$ & $\$ 30,000.00$ \\
$\mathbf{1 0}$ & Mainero & 12 & 3.6 & $\$ 540,000.00$ & $\$ 27,692.31$ \\
$\mathbf{1 1}$ & San Nicolás & 11 & 3.3 & $\$ 495,000.00$ & $\$ 25,384.62$ \\
$\mathbf{1 2}$ & San Fernando & 11 & 3.3 & $\$ 495,000.00$ & 25384.6154 \\
$\mathbf{1 3}$ & Casas & 10 & 3 & $\$ 450,000.00$ & $\$ 23,076.92$ \\
$\mathbf{1 4}$ & Jiménez & 9 & 2.7 & $\$ 405,000.00$ & $\$ 20,769.23$ \\
$\mathbf{1 5}$ & Burgos & 9 & 2.7 & $\$ 405,000.00$ & 20769.2308 \\
$\mathbf{1 6}$ & González & 8 & 2.4 & $\$ 360,000.00$ & $\$ 18,461.54$
\end{tabular}




\begin{tabular}{l|lccrc}
$\mathbf{1 7}$ & Cruillas & 8 & 2.4 & $\$ 360,000.00$ & 18461.5385 \\
$\mathbf{1 8}$ & Ocampo & 7 & 2.1 & $\$ 315,000.00$ & 16153.8462 \\
$\mathbf{1 9}$ & Mante & 6 & 1.8 & $\$ 270,000.00$ & 13846.1538 \\
$\mathbf{2 0}$ & Antigua Morelos & 5 & 1.5 & $\$ 225,000.00$ & 11538.4615 \\
$\mathbf{2 1}$ & Altamira & 4 & 1.2 & $\$ 180,000.00$ & 9230.76923 \\
$\mathbf{2 2}$ & Xicotencatl & 4 & 1.2 & $\$ 180,000.00$ & 9230.76923 \\
$\mathbf{2 3}$ & Nuevo Morelos & 3 & 0.9 & $\$ 135,000.00$ & $\mathbf{6 9 2 3 . 0 7 6 9 2}$ \\
\hline & TOTAL & $\mathbf{2 7 9}$ & $\mathbf{8 3 . 7}$ & $\mathbf{\$ 1 2 , 4 9 5 , 0 0 0 . 0 0}$ & $\mathbf{\$ 6 4 0 , 7 6 9 . 2 3}$
\end{tabular}

\subsection{Concentrations of capseicines}

Capsaicinoids are alkaloids characteristics from Capsicum, they are a complex of structural related compounds and are responsible for the hot sensation and other bioactive properties. There are 22 known compounds for Capsicum annuum, capsaicin [(6E) - N- (4-hidroxi-3-metoxibencil) -8metilnon-6-enamid] representing 69\%, the dihydrocapsaicine [6,7-Dihydrocapsaicine] $22 \%$ and the nordihydrocapsaicine [7-metil nordihydrocapsaicine] with ca. 7\% (Figure 3); the rest corresponding to capsaicinoids (homocapsaicina, norcapsaicina, homodihydrocapsaicina, nonivamida, and others) [67]; and their content may vary considerably and are responsible for the pungency and these characteristics allows the classification of some varieties as hot and some others as sweet [68]; and is mainly due to their genetic characteristics and the selection during the domestication process $[69,70]$. The wild chili pepper Capsicum annuum var. glabriusculum is very important genetically because it contains many of the desired characteristics such as the hot properties. This variety has a wide distribution and has contrasting levels of capsaicine and dihydrocapsaicine in wild populations from the south and north regions with $0.5 \mathrm{mg}$ de capsaicine /g DW for south populations (21), while populations from the north have levels of up to $56.6 \mathrm{mg}$ de capsaicine/g of dry weight [71]. In the state of Tamaulipas there are reports of studies regarding the capsaicinoids content of wild chili populatins in 15 sites from 9 municipalities in the center zone of the state i.e. Burgos, Güémez, Hidalgo, Llera, Méndez, San Carlos, Soto La Marina, Casas y Villagrán. There are many different environmental conditions in these sites and conditions for the production may include agricultural sites, thronscrubs, mezquital, tropical desciduous forests and coastal plains [55] It is believed that the variability in environmental conditions from these sites might be responsible for the capsaicinoids content variation found in the municipalities with capsaicine contents of $0.3 \mathrm{mg} / \mathrm{g}$ DW and ca. 0.1 $\mathrm{mg}$ of dihydrocapsaicine / $\mathrm{g}$ DW for ecotype from the municipality Méndez, up to $18.6 \mathrm{mg}$ of capsaicine / g DW and $8.6 \mathrm{mg}$ of dihydrocapsaicine / g DW for ecotype from the municipality Llera with a capsaicine dihydrocapsaicine content of $1.4: 1$ up to $2.5: 1$ [12,13]. These wide variations are due to the genetic and physiological conditions of the wild variety, and it represents an important phytogenetic resource to be used in genetic improvements strategies for cultivated varieties. Levels of capsaicine and dihydrocapsaicine are the main characteristics inducing the hot properties and might be related to environmental conditions from each site and other companion capsaicinoids are also important and are little known. 


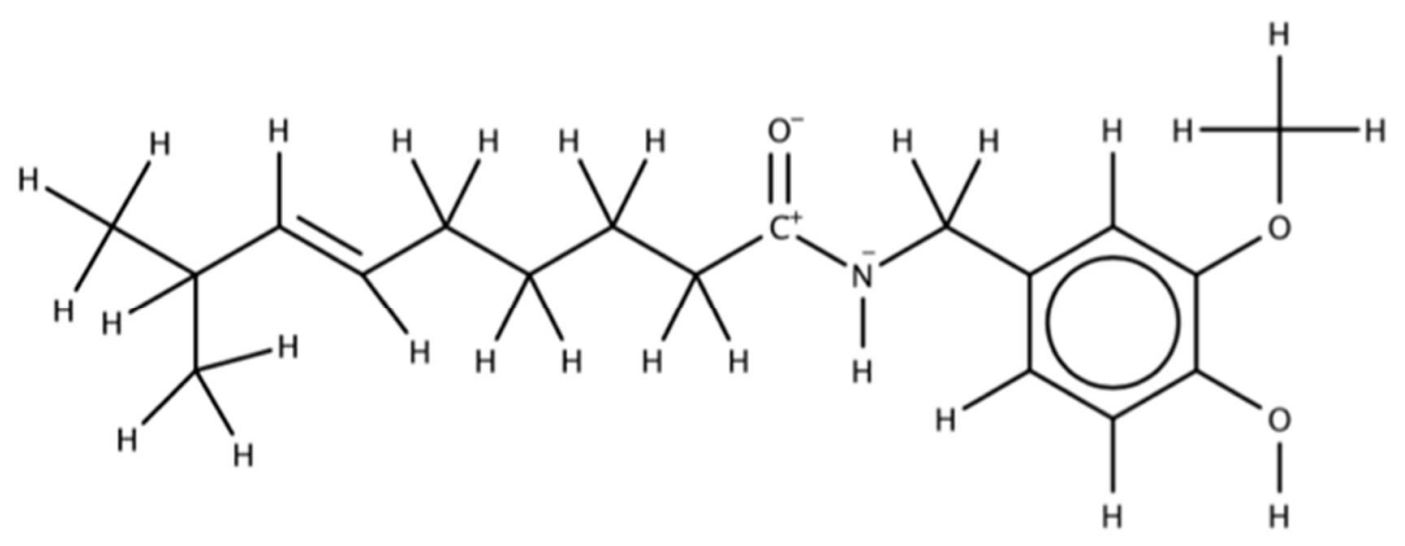<smiles></smiles>

Figure 3. Capsaicine (top) and dihydrocapsaicine (below) are structurally very similar.

\section{Conclusions}

Capsicum annuum var. glabriusculum is an economically important species in Northeastern Mexico, their fruits are consumed and sold representing an important income for many families living in rural conditions during the production at two seasons of the year. Geographic distribution is apparently limited by altitude and temperature conditions and it prefer thornscrubs and thorny bushy low forests for its growth in northeastern Mexico. Results indicate that from the states of Coahuila, Nuevo León and Tamaulipas major production occurs in the last one with 84 tons a year. The contrasting environmental conditions occurring in these zones account for the variation found in capsaicin variation both in the municipalities and ecotypes. The high demand of this product and the varied amount of capsaicinoids in fruits Capsicum annuum var. glabriusculum, are the main reasons 
for the need to increase the cultivation of this variety in intensive production systems in northeastern Mexico.

Author Contributions: J.G.M.A; C.S.V.B; R.M.G; F.E.O.S, A.M.O and A.G.P contributed to the conception of the review; J.A.T; L.U.A and F.G.O contributed with constructive discussions and translation; all authors have read and approved the manuscript.

Funding: This research received no external funding.

Acknowledgments: Authors thank the academic bodies: Ecología y Conservación de Ecosistemas (UATAM-CA-71), Ecosistemas Terrestres y Acuáticos (ITCVIC) and Manejo de Recursos Naturales y Sustentabilidad (UANL-CA-262) for the support obtained from their researchers to carry out this investigation.

Conflicts of Interest: The authors declare no conflict of interest 


\section{References}

1. Barboza, G. E.; Bianchetti, L. B., Three new species of Capsicum (Solanaceae) and a key to the wild species from Brazil. Systematic Botany 2005, 30, 863-871. DOI: 10.1600/036364405775097905.

2. Barboza, G. E., Lectotypifications, synonymy, and a new name in Capsicum (Solanoideae, Solanaceae). PhytoKeys 2011, 2, 23-38.

3. Barros, C.; Buenrostro, M. Recetario de la cocina prehispánica. https://arqueologiamexicana.mx/ediciones-especiales/e12-cocina-prehispanica (30 October 2018),

4. Bosland, P. W., Capsicums: Innovative uses of an ancient crop. In Progress in new crops, Janick, J., Ed. ASHS Press: Arlington, VA., 1996; pp 479-487.

5. Bravo, H., Estudio Botánico acerca de las solanáceas mexicanas del género Capsicum. Anales Inst. Biol. Univ. Nac. Autón. México 1934, 5, 303-321.

6. Chemin Bässler, H., Recetario pame de San Luis Potosí y Querétaro. Cocina Indígena y popular 26. Consejo Nacional para la Cultura y las Artes: México, D.F. , 2004. DOI: 9789701846810.

7. Chili Pepper Institute Statistics of chili pepper. New Mexico State University. http://www.chilepepperinstitute.org (21 08 2015),

8. D'Arcy, W. G.; Eshbaugh, W. H., New World peppers (Capsicum-Solanaceae) north of Colombia. Baileya 1974, (19), 93-103.

9. Escobar L., A., Recetario de la Sierra Gorda de Querétaro, Cocina indígena y popular 52. Consejo Nacional para las Culturas y Artes: México, D.F. , 2000; pp 165.

10. Escobar, L. A., Recetario del Semidesierto de Querétaro, cocina indígena y popular 8. Consejo Nacional para las Culturas y Artes: México, D.F. , 2000; pp 149.

11. Eshbaugh, W. H., History and exploitation of a serendipitous new crop discovery. In New crops, Janick, J.; Simon, J. E., Eds. Wiley: New York, 1993; pp 132-139.

12. Eshbaugh, W. H., Un estudio biosistemático y evolutivo de Capsicum baccatum (Solanaceae). Revista de Descripciones Botánicas; Brittonia 1970, 22, 31-43.

13. Forero, M.; Quijanob, C. E.; Pinoc, J. A., Volatile compounds of chile pepper (Capsicum annuum L. var. glabriusculum) at two ripening stages. Flavour Fragr. J. 2008, 24, 25-30. DOI: 10.1002/ffj.1913.

14. González-Jara, P.; Moreno-Letelier, A.; Fraile, A.; Piñero, D.; García-Arenal, F., Impact of human management on the genetic variation of wild pepper Capsicum annuum var. glabriusculum. PLoS ONE 2012,6, (12), 1-11. DOI: 10.1371/journal.pone.0028715.

15. Govindarajan, V. S., Capsicum production, technology, chemistry, and quality. Part II. Processed products, standards, world production and trade. Crit. Rev. Food Sci. Nutr. 1986, 25, 207-288. DOI: 10.1080/104083986095 27426.

16. Harlan, J. R., Agricultural origins: centers and no centers. Science 1971, 174, 468-474. DOI: 10.1126/science.174.4008.468.

17. Heiser, C. B.; Pickersgill, B., Names for the bird peppers (Capsicum-Solanaceae). Baileya 1975, (19), 151-153.

18. Heiser, C. B.; Smith, P. G., The cultivated capsicum peppers. Econ. Bot. 1953, 7, 214-227. DOI: 10.1007/BF02984948.

19. Hernández-Verdugo, S., A. ; González-Rodríguez; Sánchez-Peña, P.; Casas, A.; Oyama, K., Estructura y diferenciación genética de poblaciones silvestres y domesticadas de chile del noroeste de México analizada con isoenzimas y rapds. Rev. Fitotec. Mex. 2006, 29, (2), 25-29. 
20. Hernández-Verdugo, S., A.; Guevara-González, R. G.; Rivera-Bustamente, R. F.; Oyama, K., Screening wild plants of Capsicum annuum for resistance to pepper huasteco virus: presence of viral DNA and differentiation among populations. Euphytica 2001, 122, 31-36.

21. Hernández-Verdugo, S., A.; Porras, F.; Pacheco-Olvera, A.; López-España, R. G.; VillarrealRomero, M.; Parra-Terraza, S.; Enciso, T. O., Caracterización y variación ecogeográfica de poblaciones de chile (Capsicum annuum var. glabriusculum) silvestre del noroeste de México. Polibotánica 2012, 33, 175-191.

22. Hernández-Verdugo, S., A.; López España, R. G.; Sánchez-Peña, P.; Villarreal-Romero, M.; Parra-Terraza, S.; Porras, F.; Corrales-Madrid, J. L., Variación fenotípica entre y dentro de poblaciones silvestres de chile del noroeste de México. Rev. Fitotec. Mex. 2008, 31, 323-330.

23. Hunziker, A. T., Estudios sobre Solanaceae. I. Sinopsis de las especies silvestres de Capsicum de Argentina y Paraguay. Darwiniana 1950, 9, 225-247.

24. Hunziker, A. T., South American Solanaceae: A synoptic survey. In The Biology and Taxonomy of the Solanaceae. Linnean Society Symposium Series No. 7, Hawkes, J. G.; Lester, R. N.; Skelding, A. D., Eds. Academic Press, London London and New York, 1979; pp 49-85.

25. Iwai, K.; Suzuki, T.; Fujiwake, H., Simultaneous microdetermination method of capsaicin and its four analogues by HPLC and GC/MS. J. Chromatogr. A 1979, 172, 303-311. DOI: 10.1016/S0021-9673(00)90966-X.

26. Kosuge, S.; Furuta, M., Studies on the pungent principle of capsicum. Part XIV: Chemical constitution of the pungent principle. 1970, 34, 248-256.

27. Kawada, T.; Watanare, T.; Katsura, K.; Takami, H.; Iwai, K., Formation and metabolism of pungent principle of Capsicum fruit. XV. Microdetermination of capsaicin by high performance liquid chromatography with electrochemical detection. J. Chromatogr. A 1985, 329, 99-105. DOI: 10.1016/ S0021-9673(01)81899-9.

28. Krafta, K.; Brown, C. H.; Nabhan, G. P.; Luedeling, E.; Luna Ruize, J. d. J.; d'Eeckenbrugge, G. C.; Hijmans, R. J.; Geptsa, P., Multiple lines of evidence for the origin of domesticated chili pepper, Capsicum annuum, in Mexico. PNAS 2014, 111, (17), 6165-6170. DOI: 10.1073/pnas.1308933111.

29. Laborde-Cansino, J. A.; Pozo-Campodónico, O., Presente y pasado del chile en México. Publicación especial No. 85. INIA-SARH: México. , 1982.

30. Loaiza-Figueroa, F.; Ritland, K.; Laborde Cancino, J. A.; Tanksley, S. D., Patterns of genetic variation of the genus Capsicum (Solanaceae) in Mexico. Pl. Syst. Evol 1989, 165, 159-188. 10.1007/BF00936000.

31. Long-Solís, J., Capsicum y cultura: la historia de chile. Fondo de Cultura Económica: México, 1986; pp 2039681621247.

32. Long-Solís, J., Alimentos de México, el placer del chile. 2da ed.; Editorial Clío: D.F., México, 1999; pp 94.

33. Orellana-Escobedo, L.; Garcia-Amezquita, L. E.; Olivas, G. I.; OrnelasPaz, J. J.; Sepulveda, D. R., Capsaicinoids content and proximate composition of Mexican chili peppers (Capsicum spp.) cultivated in the state of Chihuahua. CYTA - J. Food 2013, 11, (2), 179-184. DOI: 10.1080/19476337.2012.716082.

34. Maiti, R. K.; Almanza, J. G.; Cárdenas, M. L.; Hernández, A., J. P.; Verde-Star, J., El chile piquín (Capsicum annuum L. var. aviculare Dierb.) D. E E., una planta con potencial agrícola para las zonas semiáridas de México. Reforma, siglo XXI. Universidad Autónoma de Nuevo León: Monterrey, N. L., 1994.

35. Mangelsdorf, P. C.; McNeish, R. S.; Willey, G. R., Origins of Middle American Agriculture. In Natural Environment and Early Cultures, West, R. C., Ed. Univ. of Texas Press: Austin, TX, USA, 1965; pp 427-445. 
36. Hernández-Verdugo, S., A.; Dávila, P.; Oyama, K., Síntesis del conocimiento taxonómico, origen y domesticación del género Capsicum. Bol. Soc. Bot. Méx 1999, 64, 65-84.

37. Martínez-Torres, H. L. Etnobotánica del chile quipín (Capsicum annuum var. glabriusculum) en la Sierra Gorda y semidesierto de Querétaro. Master, Colegio de Posgraduados Montecillo, Estado de México, México, 2007.

38. Hunziker, A. T., Genera Solanacearum: the genera of Solanaceae Illustrated, arranged according to a new system. Gantner Verlag, Ruggell, Liechtenstein: Königstein, Germany, 2001; pp 500.

39. Matucci-Cerinic, M.; Marabini, S.; Jantsch, S.; Cagnoni, M.; Partsch, G., Effects of capsaicin on the metabolism of rheumatoid arthritis synoviocytes in vitro. Ann Rheum Dis 1990,49, 5986002. DOI: 10.1136/ard.49.8.598.

40. McClung de Tapia, A., The origins of agriculture in Mesoamerica and Central America. In The Origins of Agriculture: An International Perspective, Cowan, C. W.; Watson, P. J., Eds. Smithsonian Institution Press: Washington, DC, USA, 1992; pp 143-171.

41. Medina Á., J. R., Recetario huichol de Nayarit. Cocina indígena y popular 46. Consejo Nacional para la Cultura y las Artes. México: México, D. F., 2000; pp 78.

42. Medina, T.; Rodríguez-del-Bosque, L. A.; Villalón, H.; Pozo, O.; Ramírez, M.; López, R.; Lara, M.; Gaona, G.; Cardona, A.; Mora, A., El chile piquín (Capsicum annuum L. var. aviculare) en el Noreste de México. Aspectos ecológicos y socioeconómicos. Biotam 2002, 13, 1-14.

43. Minamiyama, Y.; Kinoshita, S.; Inaba, K.; Inoue, M., Development of a cleaved amplified polyomorphic sequence (CAPS) marker linked to pungency in pepper. Plant Breed. 2005, 124, 288-291. DOI: 10.1111/j.1439-0523.2005.01101.x.

44. Montes-Hernández, S.; López-López, P.; Hernández-Verduzco, S.; Ramírez-Meraz, M., Recopilación y análisis de la información existente de las especies del género Capsicum que crecen y se cultivan en México (primer informe). INIFAP- Escuela de Agronomía, Universidad Autónoma de Sinaloa. SEMARNAT/CONABIO: D.F. MEX., 2010.

45. Montoya, B. L. C.; Gardea-Bajar, A.; Ayala-Chavéz, G. M.; Martínez-Núñez, Y. Y.; RoblesOzuna, L. E., Capsaicinoides y color en chiltepín (Capsicum annuum Var. aviculare). Efecto del proceso sobre salsas y encurtidos. Rev. Mex. Ing. Quím 2010, 9, 197-207.

46. Moreno-Ramírez, Y.; Martínez-Ávila, G.; González-Hernández, V.; Castro-López, C.; TorresCastillo, J., Free radical-scavenging capacities, phenolics and capsaicinoids in wild piquin chili (Capsicum annuum var. glabriusculum). Molecules 2018, 23, (10), 2655. DOI: 10.3390/molecules23102655.

47. Moscone, E. A.; Scaldaferro, M. A.; Grabiele, M.; M., C. N.; Sanchez, Y.; Jarret, R.; Daviña, J. R.; Ducasse, D. A.; Barboza, G. E.; Ehrendorfer, F., The evolution of chili peppers (Capsicum Solanaceae): a cytogenetic perspective. Acta Hort 2007, 745, 137-170. 10.17660/ActaHortic.2007.745.5.

48. Nabhan, G.; Slater, M.; Yarger, L., New crops small far-mers in marginal lands? Wild chiles as a case study. In Agroecology and small farm development, Altieri, M. a.; Hecht, S., Eds. CRC Press: Boca Raton: FL, USA, 1990; pp 19-34.

49. Oyama, K.; Hernández-Verdugo, S., A.; Sánchez, C.; González-Rodríguez, A.; Sánchez-Peña, P.; Garzón-Tiznado, J. A.; Casas, A., Genetic structure of wild and domesticated populations of Capsicum annuum (Solanaceae) from northwestern Mexico analyzed by RAPDs. Genet Resour Crop Evol. 2006, Genet Resour Crop Evol, (53), 553-562.

50. Pickersgill, B., Relationships between weedy and cultivated forms in some species of chili peppers (genus Capsicum). Evolution 1971, 25, 683-691. 10.1111/j.1558-5646.1971.tb01926.x.

51. Pickersgill, B., Genetic resources and breeding of Capsicum spp. Euphytica 1997, 96, (1), 129133. 
52. Pickersgill, B.; Heiser Jr., C. B.; McNeill, J., Numerical taxonomic studies on variation and domestication in some species of Capsicum. In The Biology and Taxonomy of the Solanaceae. Linnean Society Symposium Series No. 7, Hawkes, J. G.; Lester, R. N.; Skelding, A. D., Eds. Academic Press: London and New York, 1979.

53. Pickersgill, B., Migration of chili peppers, Capsicum spp. in the Americas. In Papers of the Peabody Museum of Acheology and Ethnology, for Stone D, Ed. Harvard University Press: Cambridge, Massachusetts, 1984; pp 105-123.

54. Pickersgill, B., The genus Capsicum: a multidisciplinary approach to the taxonomy of cultivated and wild plants. Biologisches Zentralblatt 1988, 107, 381-389.

55. Martínez-Ávalos, J. G.; Venegas-Barrera, C. S., Evaluación del nicho ecológico de Capsicum annuum var. glabriusculum en México. In preparation 2018.

56. Pickersgill, B., Cytogenetics and evolution of Capsicum L. In Chromosome engineering in plants: Genetics, breeding, evolution, part B, Tsuchiya, T.; Gupta , P. K., Eds. Elsevier: Amsterdam, Netherlands, 1991; pp 139-160.

57. Rodríguez del Bosque, L. A.; Ramírez, M. M.; Pozo, C. O. In El cultivo del chile piquín bajo diferentes sistemas de producción en el noreste de México, I.er Simposio Regional sobre Chile Piquín: Avances de Investigación en Tecnología de Producción y Uso Racional del Recurso Silvestre, Río Bravo, Tam., México, 2003; Río Bravo, Tam., México.

58. Rodríguez del Bosque, L. A., Preferencia del consumidor por el chile piquín en comparación con otros chiles en el noreste de México. Rev. Chapingo S. Hort 2005, 11, (2), 279-281.

59. Rodríguez del Bosque, L. A.; Ramírez, M.; Pozo, C. O., Tecnología de producción de chile piquín en el noreste de México. INIFAP-CIRNE. Campo Experimental Río Bravo, Folleto Técnico Núm. 29: Río Bravo, Tamaulipas, México, 2004; p 33.

60. SAGARPA (Secretaría de Agricultura, G., Desarrollo Rural, Pesca y Alimentación. Servicio de Información Agroalimentaria y Pesquera) „, Anuario estadístico de la producción agrícola de los Estados Unidos Mexicanos. 2012.

61. Smith Jr., C. E., Current archaeological evidence for the beginning of American agriculture. Studies in the Neolithic and urban revolutions. In The V. Gordon Childe Colloquium, Manzanilla, L., Ed. British Archaeological Reports: Oxford, UK, 1987; pp 81-101.

62. Thomas, J. F., Normal floral ontogeny and cool temperature- induced aberrant floral development in Glycine max (Fabaceae). Am J Bot 1993, 80, 429-448.

63. Torres, C. R., Las flores en la cocina mexicana. Cocina indígena y popular 22. Consejo Nacional para la Cultura y las Artes. México: D. F., México, 2000; pp 15.

64. TPL (The Plant List), Capsicum annuum var. glabriusculum (Dunal) Heiser \& Pickersgill is an accepted name. The Plant List Version 1.1: 2013.

65. Tucker, S. P., Determination of capsaicin and dihydrocapsaicin in air in a pickle processing plant. Industrial Hygiene Association Journal 2001, 62, 45-48. DOI: 10.1080/15293660108984608.

66. Vásquez, D. M. A., El amash y el pistoqué: un ejemplo de la etnoecología de los Chontales de Tabasco, México. Etnoecología 1996, 3, (4-5), 59-69.

67. Vera-Guzmán, A. M.; Chávez-Servia, J. L.; Carrillo-Rodríguez, J. C.; López, M. G., Phytochemical evaluation of wild and cultivated pepper (Capsicum annuum L. and C. pubescens (Ruiz \& Pav.) from Oaxaca, Mexico. Chil J Agr Res 2011, 71, (4), 578-585. DOI: 10.4067/S0718-58392011000400013.

68. Villalón-Mendoza, H.; Medina-Martínez, T.; Ramírez-Meráz, M., Factores de calidad de la semilla de chile silvestre (Capsicum annuum L. var. glabriusculum). Rev. Mex. Cien. For. 2012, 4, (17), 182-187. 
69. Wahyuni, Y.; Ballester, A. R.; Sudarmonowati, E.; Bino, R. J.; Bovy, A. G., Metabolite biodiversity in pepper (Capsicum) fruits of thirty-two diverse accessions: variation in healthrelated compounds and implications for breeding. Phytochemistry 2011, 72, (11-12), 1358-1370.

70. Walsh, B. M.; Hoot, S. B., The phylogenetic relationships of Capsicum (Solanaceae) using DNA sequences from two non-coding regions: The chloroplast atpB-rbcL spacer region and nuclear waxy introns. International Journal of Plant Sciences 2001, 162, (6), 1409-1418. DOI: $10.1086 / 323273$.

71. Williams, O. J.; Raghavan, G. S.; Orsat, V.; Dai, J., Microwave-assisted extraction of capsaicinoids from capsicum fruit. J Food Biochem 2004, 28, (113-122). DOI: 10.1111/ j.17454514.2004.tb00059.x. 